\title{
Impacts of shore expansion and catchment characteristics on lacustrine thermokarst records in permafrost lowlands, Alaska Arctic Coastal Plain
}

\author{
Josefine Lenz ${ }^{1,2}$ (D) $\cdot$ Benjamin M. Jones $^{3} \cdot$ Sebastian Wetterich $^{1} \cdot$ Rik Tjallingii $^{4}$. \\ Michael Fritz ${ }^{1}$ - Christopher D. Arp ${ }^{5}$ Natalia Rudaya ${ }^{6,7,8} \cdot$ Guido Grosse $^{1,2}$
}

Received: 25 May 2016/Accepted: 14 October 2016/Published online: 3 November 2016

(C) Springer-Verlag Berlin Heidelberg 2016

\begin{abstract}
Arctic lowland landscapes have been modified by thermokarst lake processes throughout the Holocene. Thermokarst lakes form as a result of ice-rich permafrost degradation, and they may expand over time through thermal and mechanical shoreline erosion. We studied proximal and distal sedimentary records from a thermokarst lake located on the Arctic Coastal Plain of northern Alaska to reconstruct the impact of catchment dynamics and morphology on the lacustrine depositional environment and to quantify carbon
\end{abstract}

Electronic supplementary material The online version of this article (doi:10.1007/s41063-016-0025-0) contains supplementary material, which is available to authorized users.

Josefine Lenz

Josefine.Lenz@awi.de

1 Department of Periglacial Research, Alfred Wegener Institute, Helmholtz Center for Polar and Marine Research, Telegrafenberg A43, 14473 Potsdam, Germany

2 Institute of Earth and Environmental Science, University of Potsdam, Karl-Liebknecht-Str. 24-25, 14476 Potsdam, Germany

3 Alaska Science Center, U.S. Geological Survey, 4210 University Drive, Anchorage, AK, USA

4 Section 5.2 Climate Dynamics and Landscape Evolution, Helmholtz Center Potsdam, GFZ German Research Center for Geosciences, Telegrafenberg C, Potsdam, Germany

5 Water and Environmental Research Center, University of Alaska Fairbanks, 306 Tanana Loop, 437 Duckering, Fairbanks, AK, USA

6 Institute of Archaeology and Ethnography, Ac. Lavrentiev Ave, 17, SB RAS, Novosibirsk 630090, Russia

7 Novosibirsk State University, Pirogova St. 2, 630090 Novosibirsk, Russia

8 Kazan Federal University, Kremlevskaya Street, 18, Kazan 420008, Russia accumulation in thermokarst lake sediments. Short cores were collected for analysis of pollen, sedimentological, and geochemical proxies. Radiocarbon and ${ }^{210} \mathrm{~Pb} /{ }^{137} \mathrm{Cs}$ dating, as well as extrapolation of measured historic lake expansion rates, were applied to estimate a minimum lake age of $\sim 1400$ calendar years BP. The pollen record is in agreement with the young lake age as it does not include evidence of the "alder high" that occurred in the region $\sim 4000 \mathrm{cal}$ yr BP. The lake most likely initiated from a remnant pond in a drained thermokarst lake basin (DTLB) and deepened rapidly as evidenced by accumulation of laminated sediments. Increasing oxygenation of the water column as shown by higher $\mathrm{Fe} / \mathrm{Ti}$ and $\mathrm{Fe} / \mathrm{S}$ ratios in the sediment indicate shifts in ice regime with increasing water depth. More recently, the sediment source changed as the thermokarst lake expanded through lateral permafrost degradation, alternating from redeposited DTLB sediments, to increased amounts of sediment from eroding, older upland deposits, followed by a more balanced combination of both DTLB and upland sources. The characterizing shifts in sediment sources and depositional regimes in expanding thermokarst lakes were, therefore, archived in the thermokarst lake sedimentary record. This study also highlights the potential for Arctic lakes to recycle old carbon from thawing permafrost and thermokarst processes.

Keywords Permafrost degradation - Carbon cycle $\cdot$ Paleoenvironment · Sedimentology · Arctic lakes · North Slope

\section{Introduction}

Permafrost degradation influences hydrology, ecology, biogeochemical cycles, and terrain stability in Arctic lowlands [34, 76, 81]. In particular, ground subsidence 
following thaw of ice-rich permafrost or melting of massive ground ice, known as thermokarst [22], has been observed and monitored during the last several decades [35, 44, 46, 74, 75]. Typical thermokarst and thaw-related landforms include retrogressive thaw slumps [52, 54], thermo-erosional gullies [12, 32], thermokarst pits [46], as well as thermokarst lakes and drained lake basins, which are the most ubiquitous features of Arctic permafrost lowlands [34, 38].

Thermokarst lake landscapes are modified by lake formation, expansion, coalescence, shrinkage, drainage and/or re-initiation, resulting in a complex topography where thermokarst basins constitute important depositional environments archiving landscape dynamics [26]. Aside from other permafrost paleo-records such as ice wedges (Siberia: Meyer et al. [59]; Alaska: Meyer at al. [60] and terrestrial deposits (e.g., Siberia: Wetterich et al. [84]; Canada: Murton et al. [68], Fritz et al. [28]; Alaska: Kanevskiy et al. [48], Wetterich et al. [83]), thermokarst lake sediments are important paleo-archives for reconstructing environmental changes on millennial time scales. Numerous studies have focused on general paleo-limnological investigations of Late Quaternary lake sediments by using various sediment and biogeochemical proxies (Lenz et al. [55]; diatoms: Biskaborn et al. [8]; plant macrofossils: Gaglioti et al. [31]). Some studies have concentrated on investigating thermokarst and geomorphological processes (Siberia: Biskaborn et al. [9]; Morgenstern et al. [66]; Schleusner et al. [77]; Canada: Coulombe et al. [19]; Fritz et al. (under review) [27]; Alaska: Farquharson et al. [24, 25], reconstructing lake generations (e.g., [41, 45, 57]) and carbon cycling (carbon accumulation rates: Klein et al. [51]; ${ }^{14} \mathrm{C}$ age offsets: Gaglioti et al. [31]; carbon degradation: Lenz et al. [57]; methane production potentials: Heslop et al. [36]).

On the Arctic Coastal Plain of northern Alaska, paleoecological lake sediment investigations are scarce aside from Wooller et al. [86] who reconstructed the past methane availability from chironomids and cladocerans for a lake near Atqasuk. Most studies have focused on mapping and classifying thermokarst lakes and drained lake basins ([30, 38, 78]; Farquharson et al. (under review)) or modern lake processes and dynamics. Here, scientific progress was achieved by research on thermokarst lake hydrogeomorphology [6], lake orientation [10, 16], geomorphic controls on lake bathymetry [39], lake thermal regimes [13], lake ice regime shifts [5], thermal talik modeling [58], and catastrophic lake drainage [42]. Under scenarios of even modest climate warming, 10-30\% of the lowland landscapes of the Arctic Coastal Plain will be affected by thermokarst [46], which could potentially impact the distribution of thermokarst lakes on the landscape. The highly dynamic nature related to the formation and drainage of thermokarst lakes in this region is particularly evident [37]. On the Arctic Costal Plain, paleo-environmental archives are scarce, and it is important to investigate past thermokarst processes and lake dynamics using sedimentary records to assess potential future landscape changes. The specific objectives of this study are:

1. to reconstruct the interaction of a late Holocene thermokarst lake with the surrounding landscape on the Arctic Coastal Plain based on analysis of sediment cores and shoreline expansion rates;

2. to assess how catchment dynamics and morphology impact the lacustrine depositional environment by comparing sediment records proximal and distal from shores;

3. to characterize and quantify how organic carbon accumulation and degradation in lacustrine thermokarst settings may be influenced by these dynamics.

\section{Study area}

The Arctic Coastal Plain of northern Alaska has been subject to several marine transgressions during the Quaternary $[14,15]$ and is divided into the older, Inner Coastal Plain (ICP) to the south which is dominated by aeolian sand and the younger, Outer Coastal Plain (OCP) to the north, which is characterized by ice-rich marine silt [38, 85]. The northern Teshekpuk Lake Special Area is situated in the low-lying younger OCP, within the zone of continuous permafrost, where an average volumetric ground ice content of $77 \%$ has been documented in nearsurface permafrost [49] and where permafrost reaches thicknesses of at least $410 \mathrm{~m}$ [47]. However, excess ice is substantially lower in sediment deeper than $4 \mathrm{~m} \mathrm{[78],}$ which limits the water depths of most thermokarst lakes to about $2.5 \mathrm{~m}$ and causes relatively uniform lake basin morphometries on the OCP [39]. Holocene permafrost degradation and lacustrine succession associated with erosion, thaw, and drainage processes have widely shaped the modern landscape [37, 45]. Today, lakes cover $22.5 \%$ of the younger OCP north of Teshekpuk Lake, whereas DTLBs occupy $61.8 \%$ [42].

Peatball Lake (informal name; $70^{\circ} 42.4^{\prime} \mathrm{N}, 153^{\circ} 55.5^{\prime} \mathrm{W}$; $3 \mathrm{~m}$ asl, above sea level) is located to the northwest of the largest lake on the Arctic Coastal Plain, Teshekpuk Lake (Fig. 1). Peatball Lake is informally named for peculiar and abundant fibric peat spheres (up to $\sim 5 \mathrm{~cm}$ diameter) that form in this lake and accumulate along a sandy shelf of the western shoreline. Peatball Lake is subcircular, has a surface area of $1.18 \mathrm{~km}^{2}$, and is $1300 \mathrm{~m}$ in diameter. The maximum water depth is $2.5 \mathrm{~m}$. Lake ice covers the lake for $\sim 9$ months of the year on average during the past 


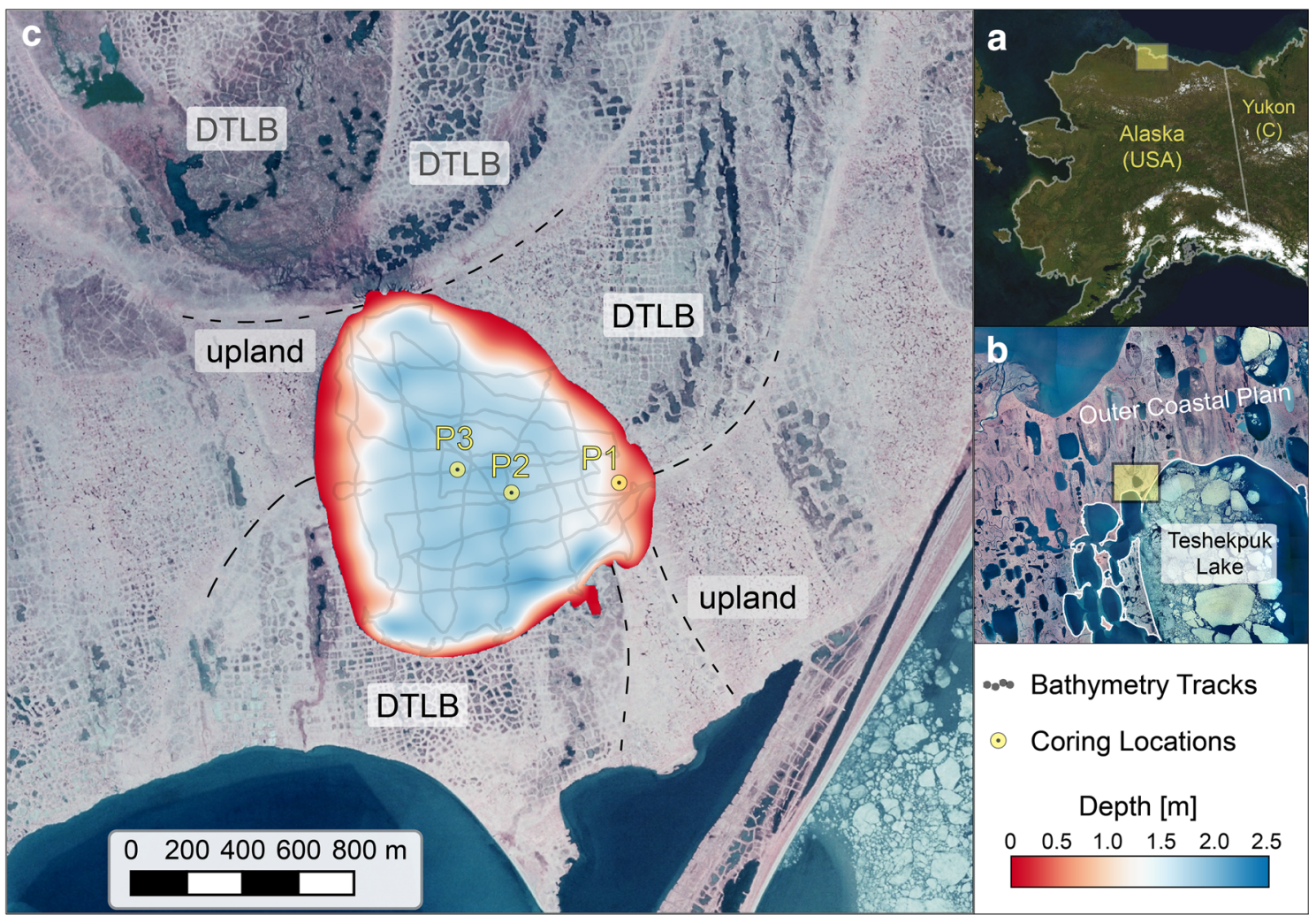

Fig. 1 Study area of in a Alaska and $\mathbf{b}$ more detailed in the northern Teshekpuk Lake Special Area on the Outer Coastal Plain and c location of Peatball Lake indicating coring sites $(P 1, P 2, P 3)$ and core Tes-UPL-2 (S. Jock, unpublished data). Background of main

4 years of monitoring, and maximum ice thickness is typically $1.5-2.0 \mathrm{~m}$ over the same period [4]. Water quality parameters monitored for different seasons and years (2012-2015) are summarized in Table 1. Water temperatures ranged from about $5-14{ }^{\circ} \mathrm{C}$ in August to about $0-1{ }^{\circ} \mathrm{C}$ below the ice cover in April. Uniform temperature, $\mathrm{pH}$, and specific conductivity (SC) in different depths confirm a well-mixed water body of the shallow lake in summer and are indicative for a cold-monomictic lake circulation. SC is up to four times higher under the lake ice in April, because ion content increases in the remaining liquid phase during the freezing. Lake water conditions are oxic in summer and can become hypoxic in winter, e.g., $0.2 \mathrm{mg} \mathrm{L}^{-1}$ in April 2012 (Table 1). Chlorophyll- $a$, an indicator for algal biomass, points towards an oligo- to mesotropic lake system, although it is highly variable throughout the year (1-15 $\mathrm{mg} \mathrm{L}^{-1}$ ) and essentially higher under the winter lake ice.

The study area is dominated by high- and low-centered polygonal tundra. The cover is characterized by wetland vegetation with wet graminoids and moss communities [70]. The modern regional climate is characterized by mean annual air temperatures of $-12.2{ }^{\circ} \mathrm{C} \quad\left(T_{\mathrm{Jan}}\right.$ uary $-27.5^{\circ} \mathrm{C}, T_{\text {July }} 4.3{ }^{\circ} \mathrm{C}$ ) and low average precipitation of map: Color infrared aerial orthoimage mosaic, 2002. Note the presence of drained thaw lake basins (DTLB) and upland remains as well as the abundance of ice wedge polygonal landforms with high ground ice contents in near-surface permafrost

$113 \mathrm{~mm} \mathrm{yr}^{-1}$ in Barrow (120-km NW of Peatball Lake) (www.climate-data.org).

\section{Materials and methods}

Three short cores were recovered from Peatball Lake by using a piston corer (Aquatic Research Instruments, Hope, ID, USA) operated from the lake ice (April 2014) or inflatable coring platform (August 2014): Two cores of 49and 100-cm length were obtained from the lake center (core ID P3 (PG2372) in April and core ID P2 (PG2371) in August 2014) and one core (core ID P1 (PG2370) in August 2014) of 50-cm length was collected near the SW shore (Table 2).

Split sediment cores were visually described and photographed at the German Research Center for Geosciences Potsdam (GFZ). Magnetic susceptibility (MS) was measured every $0.1 \mathrm{~cm}$ with a split core logger (scl-2.3) developed at GFZ that was equipped with a Bartington MS2E sensor in combination with an MS2 control unit [69]. The geochemical sediment composition was acquired by X-ray fluorescence (XRF) core scanning using an ITRAX core scanner [20]. The XRF core scanner was 
Table 1 Hydrochemical characteristics of Peatball Lake in different water depths and from different seasons (CALON project: http://www. arcticlakes.org/)

\begin{tabular}{|c|c|c|c|c|c|c|c|c|}
\hline Month & Year & $\begin{array}{l}\text { Water } \\
\text { depth }(\mathrm{m})\end{array}$ & $\mathrm{pH}$ & $\begin{array}{l}\text { Specific conductivity } \\
\left(\mu \mathrm{S} \mathrm{cm}^{-1}\right)\end{array}$ & $\begin{array}{l}\text { Temperature } \\
\left({ }^{\circ} \mathrm{C}\right)\end{array}$ & $\begin{array}{l}\text { Dissolved oxygen } \\
\left(\mathrm{mg} \mathrm{L}^{-1}\right)\end{array}$ & $\begin{array}{l}\text { Dissolved } \\
\text { oxygen }(\%)\end{array}$ & $\begin{array}{l}\text { Chlorophyll- } a \\
\left(\mathrm{mg} \mathrm{L}^{-1}\right)\end{array}$ \\
\hline April & 2012 & 2.3 & - & 3170 & 1.1 & 0.2 & 2 & - \\
\hline August & 2012 & 0.5 & 7.07 & 712 & 13.7 & 10.6 & 103 & 7.07 \\
\hline August & 2012 & 1.3 & 7.04 & 712 & 13.7 & 10.4 & 101 & 7.04 \\
\hline April & 2013 & 2.0 & - & 1780 & -0.2 & 15 & - & 14.9 \\
\hline August & 2013 & 1.0 & - & 744 & 10.4 & 11.7 & 105 & 1.2 \\
\hline August & 2013 & 2.0 & - & 744 & 10.4 & 11.7 & 105 & 2.1 \\
\hline April & 2014 & 2.0 & 6.69 & 2113 & 0.2 & 17 & 6.7 & 4.7 \\
\hline August & 2014 & 0.5 & 7.14 & 704 & 5.3 & 12.6 & 100 & 2.9 \\
\hline April & 2015 & 2.0 & 7.07 & - & 0.0 & 6 & 6.9 & - \\
\hline August & 2015 & - & - & 667 & 9.3 & - & - & - \\
\hline
\end{tabular}

Table 2 Meta data of the three cores from Peatball Lake

\begin{tabular}{llccrr}
\hline Core ID & Location & Core length $(\mathrm{cm})$ & Water depth $(\mathrm{cm})$ & Coordinates & Date of coring \\
\hline $\begin{array}{l}\text { P1 } \\
(\mathrm{PG} 2370)\end{array}$ & Nearshore & 50 & 148 & $70^{\circ} 42.349^{\prime} \mathrm{N}, 153^{\circ} 54.527^{\prime} \mathrm{W}$ & 15 August 2014 \\
$\begin{array}{l}\text { P2 } \\
(\mathrm{PG} 2371)\end{array}$ & Center & 100 & 215 & $70^{\circ} 42.328^{\prime} \mathrm{N}, 153^{\circ} 55.133^{\prime} \mathrm{W}$ & 15 August 2014 \\
$\begin{array}{l}\text { P3 } \\
(\mathrm{PG} 2372)\end{array}$ & Center & 49 & 230 & $70^{\circ} 42.368^{\prime} \mathrm{N}, 153^{\circ} 55.454^{\prime} \mathrm{W}$ & 20 April 2014 \\
\hline
\end{tabular}

operated with a Cr X-ray source $(30 \mathrm{kV}, 300 \mathrm{uA}, 10 \mathrm{~s})$ and provides element intensities. Element intensities are nonlinear functions of element concentrations due to physical sediment properties (e.g., water content), the sample geometry, and XRF absorption, and enhancement effects [80]. However, down-core variations in physical properties and sample geometric effects can be minimized by using (log-) ratio of the intensity data [82].

The cores were subsampled at $1-\mathrm{cm}$ intervals for geochemical analyses. Total nitrogen (TN), total carbon (TC), and total organic carbon (TOC) were measured on bulk sediments with an elemental analyzer (ElementarVario EL III; analytical accuracy of $\pm 0.1 \mathrm{wt} \%$ ) and the C/N-ratio (TOC/TN) was calculated. To determine the stable carbon isotope composition, $\delta^{13} \mathrm{C}$ of TOC was analyzed at GFZ with a Carlo-Erba CN2500 attached to a stable isotope ratio mass spectrometer (DELTAplusXL, Finnigan). Values of $\delta^{13} \mathrm{C}$ are expressed relative to the Vienna Pee Dee Belemnite (V-PDB) standard in per mill (\%o), and the standard deviation $(1 \sigma)$ is generally better than $\pm 0.02 \%$. The water content was calculated using the weight difference between fresh and freeze-dried bulk sediment samples and is expressed as weight percentage (wt \%).

A total of 24 pollen samples were processed in an average interval of $4 \mathrm{~cm}$ from core $\mathrm{P} 2$, each consisting of 2-3 g of dry sediment. Sample preparation followed common protocols $[7,23,65]$ including the addition of Lycopodium spore tablets (Batch number 1031; $n=20,848)$ to calculate total pollen and spore concentration. The bulk samples were processed with hydrochloric acid, potassium hydroxide, and hydrofluoric acid (40\%). Afterwards, samples were treated to $3 \mathrm{~min}$ of acetolysis, for staining the pollen grains, and an ultrasonic bath (max. $30 \mathrm{~s}$, mesh size $7 \mu \mathrm{m}$ ) was applied to remove small pollutants. Pollen residues mounted in glycerol were analyzed under the light microscope with a $400 \times$ magnification. Identification of pollen and spores was performed using reference pollen collections and regional pollen atlases (e.g., [71, 72]).

Accelerator mass spectrometry (AMS) radiocarbon dating was performed at the Poznan Radiocarbon Laboratory (Poland) on three samples of core P1, ten samples of core P2, and four samples of P3. Samples were wet-sieved through $>250-\mathrm{mm}$ mesh screens and hand-picked for macrofossil remains, except for two samples at the base of core P2 which were dated as bulk samples. Results were calibrated using the CALIB 7.1 with the IntCal13 data set [73] and reported in calibrated years before $1950 \mathrm{AD}$, referred as before present (cal yr BP).

Dried sediment samples from core $\mathrm{P} 2$ were analyzed in an interval of $0.5 \mathrm{~cm}$ for ${ }^{210} \mathrm{~Pb},{ }^{226} \mathrm{Ra}$, and ${ }^{137} \mathrm{Cs}$ by direct gamma assay in the Liverpool University Environmental 
Radioactivity Laboratory using Ortec HPGe GWL series well-type coaxial low background intrinsic germanium detectors [2]. ${ }^{210} \mathrm{~Pb}$ was determined via its gamma emissions at $46.5 \mathrm{keV}$, and ${ }^{226} \mathrm{Ra}$ by the 295 and $352 \mathrm{keV} \gamma$ rays emitted by its daughter isotope ${ }^{214} \mathrm{~Pb}$ following 3 weeks storage in sealed containers to allow radioactive equilibration. ${ }^{137} \mathrm{Cs}$ was measured by its emissions at $662 \mathrm{keV}$. The absolute efficiencies of the detectors were determined using calibrated sources and sediment samples of known activity; corrections were made for the effect of self-absorption of low energy $\gamma$-rays within the sample [3].

Erosion rates for Peatball Lake were determined by comparing the lake shoreline in aerial photography acquired in 1955 and 2002. The 2002 orthophotography (2.5-m resolution) served as the base in which to georegister the 1955 photography to a resolution of $2.5 \mathrm{~m}$. The mean RMS error associated with the georegistration of the 1955 photography was $0.78 \mathrm{~m}$ using 13 ground control points and a third-order polynomial transformation. The lake shoreline was manually digitized in both images and then erosion rates calculated using the USGS Digital Shoreline Analysis System add-on for ArcMap [79]. While this method is intended for measuring coastal shoreline erosion, it has also been successfully used to quantify thermokarst lake expansion previously [6, 43]. Thus, lake expansion rates were measured at 10-m transect intervals along the lake shoreline between 1955 and 2002 to help further constrain the age of Peatball Lake.

\section{Results}

Sediment parameters were analyzed to characterize the past depositional environment of Peatball Lake. The combination of visual sediment core description with MS and XRF core scanning results provides a detail characterization of the core lithology and sediment facies. In the sediments of Peatball Lake, magnetic minerals are restricted to siliciclastic sediments that originate from input of allochthonous material into the lake. Additional information on the origin or grain-size of siliciclastic sediments is obtained by variations of the K/Ti XRF scanning record. The Fe/Ti and $\mathrm{Fe} / \mathrm{S}$ ratios provide information on relative changes of the oxygenation in the lake, which is linked with water depth in Peatball Lake. Geochemical analyses of TN and TOC indicates past bioproductivity, allochthonous input of organic material into the lake system but also reflects preservation conditions of organic matter [17, 53]. As $\mathrm{CaCO}_{3}$ is presumably produced only autochthonously in lakes and is not present in the terrestrial terrain on the younger OCP, it indicates deposition of lacustrine biogenic carbonates. $\mathrm{CaCO}_{3}$ and TOC may vary due to a dilution effect of the other. The $\mathrm{C} / \mathrm{N}$-ratio characterizes the degree of decomposition of organic material but can also be used to discriminate sources or organic matter by using the ratio of $\delta^{13} \mathrm{C}$ and $\mathrm{C} / \mathrm{N}[62,64]$. Changing abundance and taxa composition of pollen grains in the sediment gives evidence for regional vegetation composition but is also influenced by changing sources of sediment into the lake.

\section{Sedimentological results of nearshore core P1 (PG2370)}

Core P1 was dominated by homogenous minerogenic sediment composed of dark gray (Munsell Soil Color Chart, ID 2.5Y 4/1) fine sands (Fig. 2). A peat inclusion of $1.5 \mathrm{~cm}$ in diameter was described in $17 \mathrm{~cm}$ depth as well as organic layers $(2.5 \mathrm{Y} 3 / 2)$ of $2 \mathrm{~mm}$ thickness in depth of $36-46 \mathrm{~cm}$. The base of the core was composed of a $4-\mathrm{cm}-$ thick, black organic deposit (2.5Y 1.5/1), which was poorly decomposed and included a root of $7 \mathrm{~mm}$ length. The MS of the core ranged from 5 to 103 with distinct changes combined with up-core increasing MS at 45, 31, and $20 \mathrm{~cm}$. The $\mathrm{K} / \mathrm{Ti}$ record shows some variation, but no obvious trend in core $\mathrm{P} 1$. In contrast, $\mathrm{Fe} / \mathrm{Ti}$ and $\mathrm{Fe} / \mathrm{S}$ were low and showed no variation in most of the sediment core, but high values occur at the black organic deposit of the basal part of the core.

$\mathrm{TN}$ was $0.2 \mathrm{wt} \%$ on average $\left(\mathrm{TN}_{\min }\right.$ below detection limit of $0.1 \mathrm{wt} \%$ mainly in $13-34 \mathrm{~cm}$ depth, $\mathrm{TN}_{\max } 0.6$ $\mathrm{wt} \%$ at the core base) and TOC was on average $1.6 \mathrm{wt} \%$ (TOC $_{\text {min }}$ below detection limit of $0.1 \mathrm{wt} \%$ at $15-22 \mathrm{~cm}$ depth, $\mathrm{TOC}_{\max } 13.3 \mathrm{wt} \%$ at the core base). The $\mathrm{C} / \mathrm{N}$-ratio was calculated to an average of 8.7 with presumably low $\mathrm{C} / \mathrm{N}$ where TN and TOC reached the detection limit and a maximum of 25.4 at the core base. $\mathrm{CaCO}_{3}$ calculated from TIC was $4.5 \%$ on average with $\mathrm{CaCO}_{3 \text { min }}$ of $2.9 \%$ and $\mathrm{CaCO}_{3 \max }$ of $11.8 \%$. A narrow $\delta^{13} \mathrm{C}$ range of -28.2 to $-27.2 \%$ was measured for core P1.

\section{Sedimentological and palynological results of lake center-cores P2 (PG2371; and P3 (PG2372))}

Sediments of core P3 from the lake center are covering the same facies as the upper half of the 100-cm long core P2 from near the lake center. Subsequently, we will concentrate on core P2 (Fig. 3, for analytical details of core P3 see Supplementary materials 1 and 2).

Core P2 was mostly well laminated with alternating dark grayish brown $(2.5 \mathrm{Y} 4 / 2)$, silty minerogenic sediments and black (2.5 Y 2.5/1) organic layers of up to $5 \mathrm{~mm}$ thickness. Minerogenic deposits without visible organics and no clear laminations characterize core P2 between 71 and $87 \mathrm{~cm}$. Thinner laminae were observed in depths of $87-99 \mathrm{~cm}$. The base of the core P2 was composed of a very dark gray (2.5Y 3/1) and fairly decomposed peat layer. Core P3 


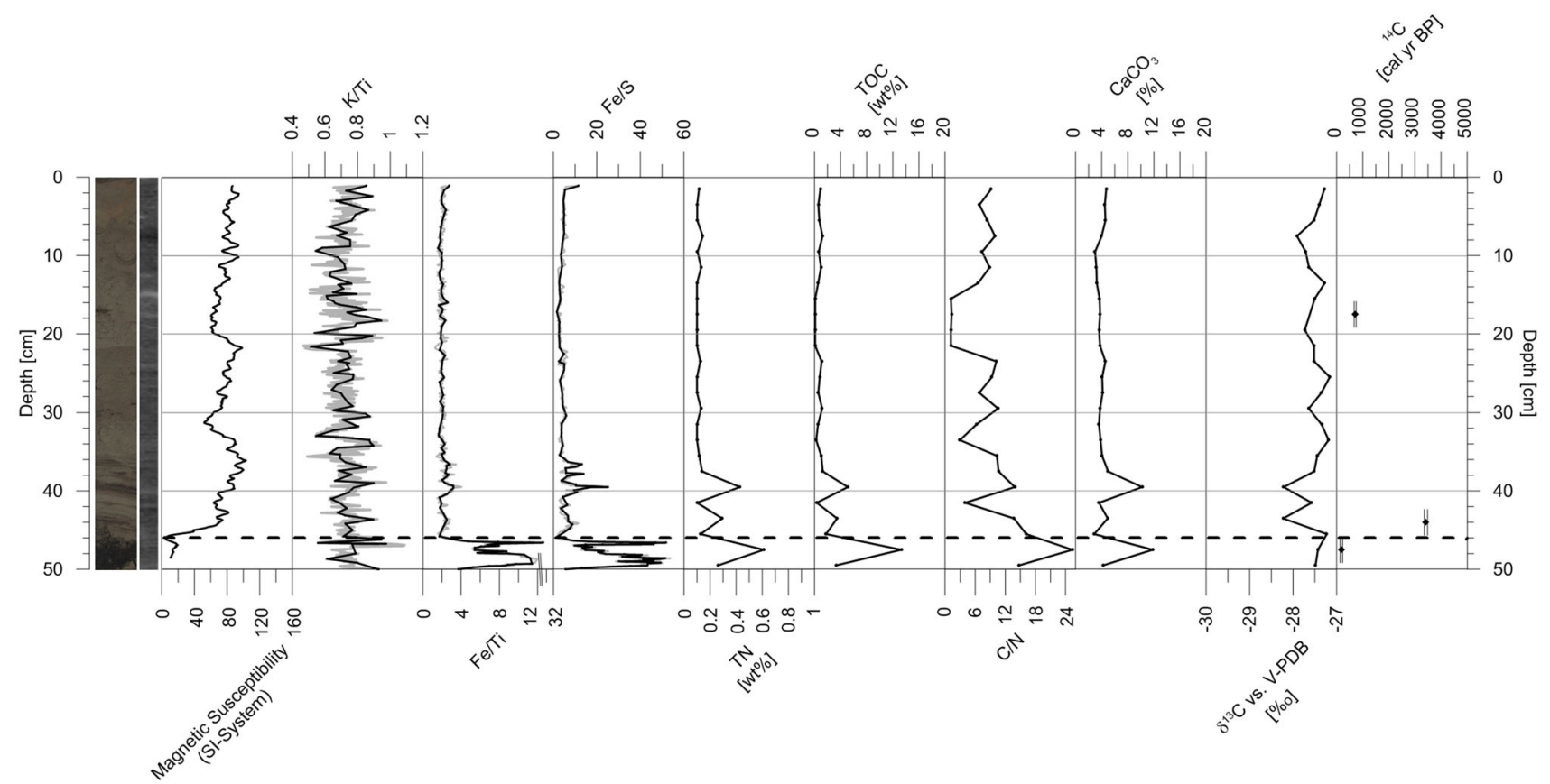

Fig. 2 Core photograph, radiographic image, lithological and geochemical results, and radiocarbon dates of core P1 according to core depth. Please see the Supplementary material 3 for higher resolution core photographs and radiographic images of P1

differed only in its thickness of organic (1-10 mm) and minerogenic layers $(2-30 \mathrm{~mm})$ and the presence of a bivalve mollusk of 4 -mm length at $31 \mathrm{~cm}$ depth. The MS of the sediment core P2 ranged from 7 to 151 (36-94 in core $\mathrm{P} 3$ ) with a pronounced change to increasing MS from 87 to $64 \mathrm{~cm}$ and decreasing MS from 64 to $50 \mathrm{~cm}$.

Similar to core P1, the K/Ti record was highly variable but showed no trend within core P2; except for a narrow $\mathrm{K} / \mathrm{Ti}$ ratio shown at $55-56 \mathrm{~cm}$ (Fig. 3). The $\mathrm{Fe} / \mathrm{Ti}$ ratio showed low variation in depths of $100-50 \mathrm{~cm}$ and higher variation and ratio with slightly increasing trend in depth of $50-0 \mathrm{~cm}$. Similarly, the $\mathrm{Fe} / \mathrm{S}$ ratio was very low at $87-100 \mathrm{~cm}$ and increased up-core with high variations in depth of $0-38 \mathrm{~cm}$.

$\mathrm{TN}$ was on average $0.5 \mathrm{wt} \%\left(\mathrm{TN}_{\min }\right.$ below $0.1 \mathrm{wt} \%$ only at $61-62 \mathrm{~cm}, \mathrm{TN}_{\max } 0.93 \mathrm{wt} \%$ at $\left.96-97 \mathrm{~cm}\right)$, and TOC was on average $7.0 \mathrm{wt} \%\left(\mathrm{TC}_{\min } 0.53 \mathrm{wt} \%, \mathrm{TOC}_{\max } 19.1 \mathrm{wt} \%\right.$ at 96-97 cm), both with lowest values between 52 and $69 \mathrm{~cm}$. The $\mathrm{C} / \mathrm{N}$-ratio was decreasing up-core from a maximum of 24 at $96-97 \mathrm{~cm}$ to a minimum of 12 at $60 \mathrm{~cm}$ and remained stable around 14 in $0-60 \mathrm{~cm}$ depth. $\mathrm{CaCO}_{3}$ varied between 1.4 and $16.8 \%$ with $\mathrm{CaCO}_{3 \min }<4 \%$ between 48 and $69 \mathrm{~cm}$. The $\delta^{13} \mathrm{C}$ ranged between -29.3 and $-27.4 \%$ in core P2 with highest $\delta^{13} \mathrm{C}$ of $\geq-28 \%$ in depth of 54 and $69 \mathrm{~cm}$.

Pollen analysis revealed high pollen concentration (Fig. 4) that allowed counting up to 300 grains in each sample. Two pollen zones (PZ) were identified in the pollen diagram of core $\mathrm{P} 2$ based on changing pollen taxa composition and abundances (Fig. 4): PZ I (101-72 cm) was characterized by almost equal percentages of Poaceae and Cyperaceae. The abundance of planktonic green algae remnants (Botryococcus, Pediastrum, and Zygnema) increased in PZ I. PZ II $(72-0 \mathrm{~cm})$ was characterized by dominance of Cyperaceae over Poaceae and a decrease in planktonic green algae. Upright shrub pollen of Betula, Alnus, and Salix dominated over Picea and Pinaceae in both pollen zones PZ I and PZ II.

\section{Lake age estimation}

Calibrated ages ranged between 180 and 3420 cal yr BP for core P1; between 530 and 4200 cal yr BP for core P2; and between 1300 and $3180 \mathrm{cal}$ yr BP for core P3, but did not show a clear age-depth relationship (Table 3). While the near-surface date $(1-2 \mathrm{~cm})$ in core P2 had the youngest age of the geochronological record, the second youngest date in this core was obtained at the core base. Here, three samples (bulk and plant remains) yielded similar radiocarbon age between 1370 and $1470 \mathrm{cal}$ yr BP.

Total ${ }^{210} \mathrm{~Pb}$ activity significantly exceeded the supporting ${ }^{226} \mathrm{Ra}$ in the uppermost $3 \mathrm{~cm}$ of core $\mathrm{P} 2$. The measured ${ }^{210} \mathrm{~Pb}$ inventory of the core corresponds to a mean ${ }^{210} \mathrm{~Pb}$ supply rate of $9 \mathrm{~Bq} \mathrm{~m}^{-2} \mathrm{yr}^{-1}$. Although being very low, the ${ }^{210} \mathrm{~Pb}$ supply rate lies within the expected range for this region given the very low mean annual rainfall at this site $\left(<200 \mathrm{~mm} \mathrm{yr}^{-1}\right)$. The ${ }^{137} \mathrm{Cs}$ concentrations in $\mathrm{P} 2$ were significant in the uppermost $3 \mathrm{~cm}$ of the core P2. Although 


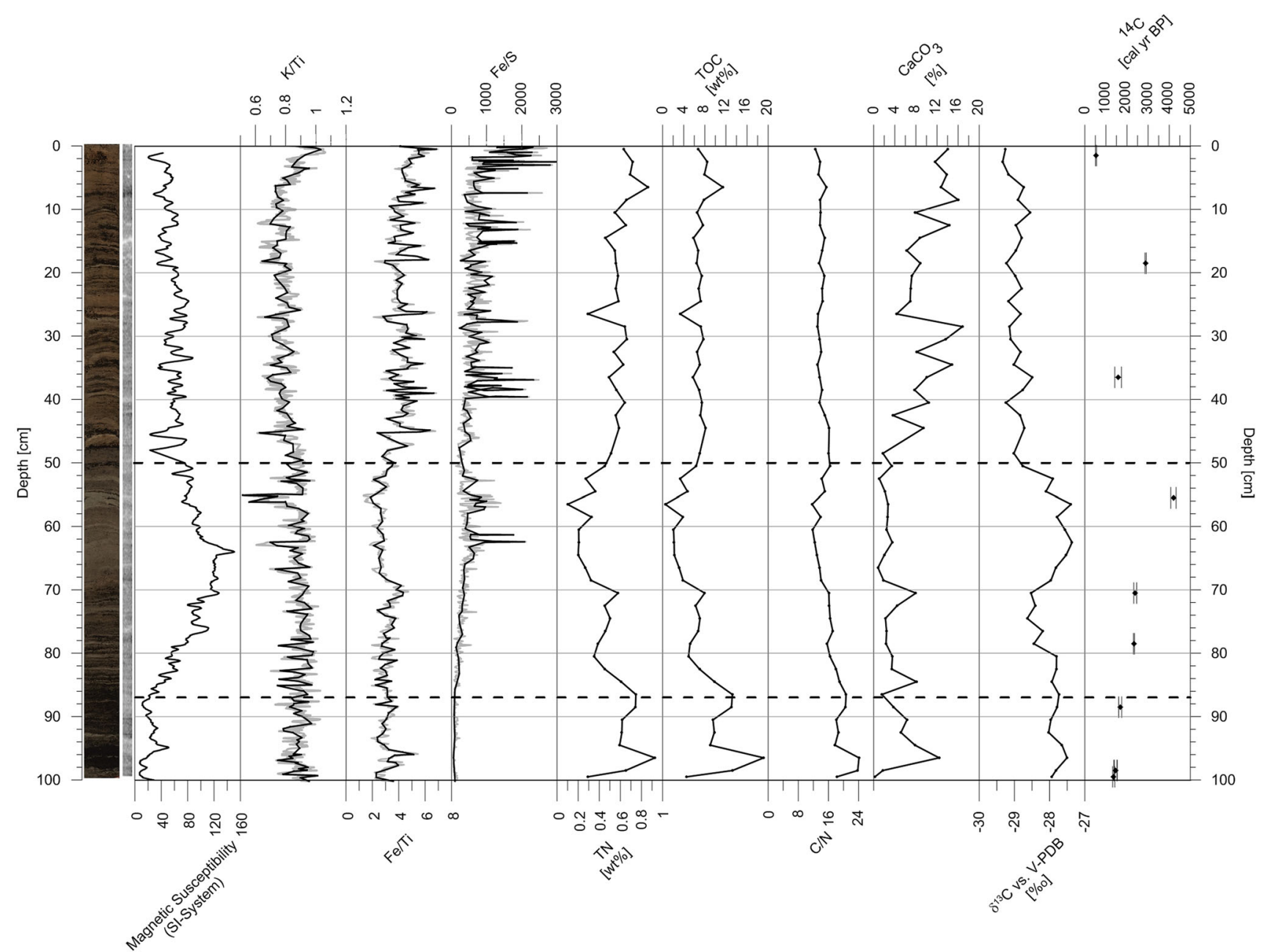

Fig. 3 Core photograph, radiographic image, lithological and geochemical results, and radiocarbon dates of core P2 according to core depth. Please see the Supplementary material 3 for higher resolution core photographs and radiographic images of P2 and P3

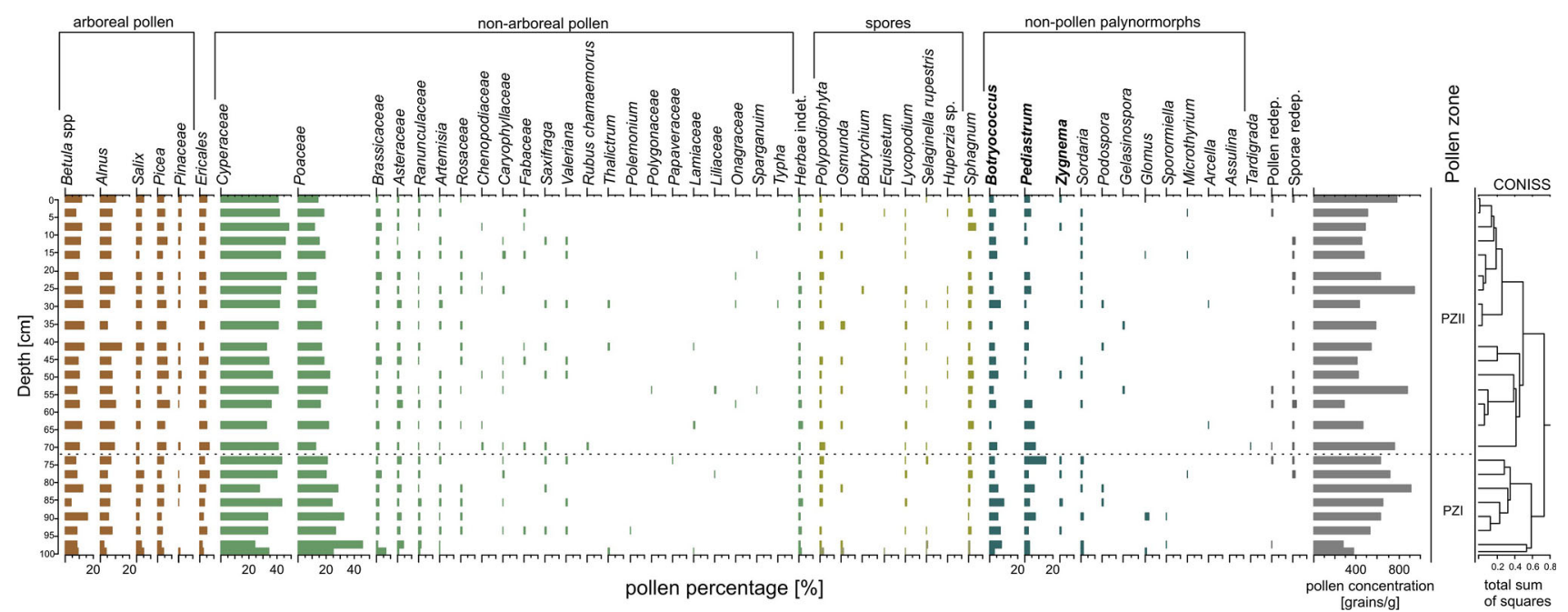

Fig. 4 Pollen diagram of samples from core P2 produced with the TILIA software. The visual definition of pollen zones is supported by cluster analysis with the program CONISS [33]. Algae-derived non-pollen palynomorphs in bold letters 
Table 3 AMS radiocarbon age determinations of three cores (P1, P2 and P3) with calibrated ages derived from Calib 7.1

\begin{tabular}{|c|c|c|c|c|c|c|c|}
\hline $\begin{array}{l}\text { Core } \\
\text { ID }\end{array}$ & Lab ID & $\begin{array}{l}\text { Depth } \\
(\mathrm{cm})\end{array}$ & Dated material & $\begin{array}{l}\delta^{13} \mathrm{C}[\% \\
\mathrm{V}-\mathrm{PDB}]\end{array}$ & $\mathrm{pMC}$ & $\begin{array}{l}\text { AMS }{ }^{14} \mathrm{C} \\
\text { age (yr BP) }\end{array}$ & $\begin{array}{l}\text { Calibrated }{ }^{14} \mathrm{C} \text { age } \\
\text { (cal yr BP) }\end{array}$ \\
\hline P1 & Poz-68412 & $17-18$ & Moss remains, Cyperaceae remains & -36.7 & 90.74 & $780 \pm 30$ & $710 \pm 40$ \\
\hline P1 & Poz-68413 & $43.5-44.5$ & $\begin{array}{l}\text { Moss remains, small wooden remains, remains of } \\
\text { leaves }\end{array}$ & -31.0 & 67.17 & $3195 \pm 35$ & $3420 \pm 60$ \\
\hline $\mathrm{P} 1$ & Poz-68414 & $47-48$ & $\begin{array}{l}\text { Wood, single moss remains, roots, some Cyperaceae } \\
\text { remains }\end{array}$ & -27.5 & 97.98 & $165 \pm 30$ & $180 \pm 50$ \\
\hline $\mathrm{P} 2$ & Poz-68415 & $1-2$ & Moss remain & -36.6 & 93.69 & $525 \pm 30$ & $530 \pm 25$ \\
\hline $\mathrm{P} 2$ & Poz-68417 & $18-19$ & Cyperaceae remains, moss leflets & -32.1 & 71.82 & $2660 \pm 30$ & $2880 \pm 30$ \\
\hline $\mathrm{P} 2$ & Poz-68664 & $36-37$ & Mollusk shell & -21.0 & 79.90 & $1690 \pm 70$ & $1580 \pm 160$ \\
\hline $\mathrm{P} 2$ & Poz-68418 & $55-56$ & Moss remains, wooden remains, single seeds & -32.0 & 62.30 & $3800 \pm 35$ & $4200 \pm 125$ \\
\hline $\mathrm{P} 2$ & Poz-68479 & $70-71$ & Cyperaceae remains, moss remains & -30.6 & 74.65 & $2350 \pm 30$ & $2390 \pm 70$ \\
\hline $\mathrm{P} 2$ & Poz-68480 & $78-79$ & Cyperaceae remains, moss remains & -31.2 & 75.17 & $2295 \pm 30$ & $2330 \pm 25$ \\
\hline $\mathrm{P} 2$ & Poz-68481 & $88-89$ & Cyperaceae remains, moss remains & -31.3 & 80.18 & $1775 \pm 30$ & $1680 \pm 70$ \\
\hline $\mathrm{P} 2$ & Poz-68482 & $98-99$ & Moss stems and moss leaves, wooden remains, seed & -30.2 & 82.45 & $1550 \pm 30$ & $1450 \pm 75$ \\
\hline $\mathrm{P} 2$ & Poz-70802 & $98-99$ & Bulk sediment & -23.1 & 82.23 & $1571 \pm 30$ & $1470 \pm 70$ \\
\hline $\mathrm{P} 2$ & Poz-70804 & 99-100 & Bulk sediment & -26.9 & 82.86 & $1510 \pm 30$ & $1370 \pm 50$ \\
\hline P3 & Poz-68483 & $15-16$ & $\begin{array}{l}\text { Moss remains, Cyperaceae remains, aquatic plant } \\
\text { remains }\end{array}$ & -34.3 & 68.74 & $3010 \pm 35$ & $3180 \pm 85$ \\
\hline $\mathrm{P} 3$ & Poz-68484 & $33-34$ & $\begin{array}{l}\text { Moss remains, Cyperaceae remains, roots, aquatic } \\
\text { plant remains }\end{array}$ & -34.7 & 69.82 & $2890 \pm 40$ & $3000 \pm 120$ \\
\hline P3 & Poz-68485 & $42-44$ & Moss, aquatic plant remains & -36.3 & 84.29 & $1375 \pm 30$ & $1300 \pm 70$ \\
\hline P3 & Poz-68486 & $46-47$ & Moss remains, Cyperaceae remains & -32.4 & 78.16 & $1980 \pm 30$ & $1930 \pm 60$ \\
\hline
\end{tabular}

Poz Poznan Radiocarbon Laboratory, $p M C$ percent modern carbon

there was no discernible subsurface peak, the results do suggest that the 1963 fallout maximum from the atmospheric testing of nuclear weapons is recorded in sediments lying between 1 and $2.5 \mathrm{~cm}$ depth, with a mid-point of the fallout inventory at $1.5 \mathrm{~cm}$. Low sedimentation rates of $0.04 \mathrm{~cm} \mathrm{yr}^{-1}\left(0.021 \mathrm{~g} \mathrm{~cm}^{-2} \mathrm{yr}^{-1}\right)$ were calculated from the ${ }^{210} \mathrm{~Pb}$ concentration. An age of 2100 years was calculated for the base of core P2 when assuming a constant sedimentation rate. Analytical details are available in Supplementary material 4.

A third independent age estimation of Peatball Lake is based on determining the shoreline expansion rates (Fig. 5) and inverting the expansion with the assumption of stable rates to retrieve the potential timing of lake initiation. A maximum shoreline erosion of $1.36 \mathrm{~m} \mathrm{yr}^{-1}$ was calculated at the upland bluff to the southeast and the modern outflow to the north of Peatball Lake; a minimum of $0.02 \mathrm{~m} \mathrm{yr}^{-1}$ was determined at the western shoreline. Applying the mean shoreline expansion rate of $0.46 \mathrm{~m} \mathrm{yr}^{-1}$ to the lake radius of about $650 \mathrm{~m}$ and assuming a constant radial lake expansion from a central point, a lake initiation around 1400 years ago is calculated $\left(650 \mathrm{~m} / 0.46 \mathrm{~m} \mathrm{yr}^{-1}=1413 \mathrm{yr}\right)$. This calculation provides an independent, yet crude assessment for limiting the initiation age of Peatball Lake.

\section{Discussion}

\section{Thermokarst lake development}

The development of Peatball Lake can be reconstructed from the sediment cores and the calculated shoreline expansion rates. Deriving a clear age-depth relationship for sediments in Peatball Lake is challenging, but the lake initiation is set to a minimum age of 1400 years based on the following arguments: Triplicate radiocarbon measurements of different materials (bulk sediment and plant macrofossils) at slightly different depths in core P2 generated similar calibrated radiocarbon ages of about 1400 cal yr BP. ${ }^{210} \mathrm{~Pb} /{ }^{137} \mathrm{Cs}$ dating yielded a maximum age of about $2100 \mathrm{yr}$ BP for the core base when assuming a constant sedimentation rate of $0.04 \mathrm{~cm} \mathrm{yr}^{-1}$. However, constant sediment accumulation is not realistic in dynamic thermokarst lake environments where intermittent rapid lake expansion can cause slumping and mass deposition $[9,29,55]$. Therefore, a minimum age of core P2 of $1400 \mathrm{yr}$ BP seems reasonable and is supported by the modern mean shoreline expansion rate of $0.46 \mathrm{~m} \mathrm{yr}^{-1}$ (for 1955-2002 AD) leading to a lake initiation age of around 1400 years before today. The pollen record suggests that major shifts in vegetation did not occur (Fig. 4). The 
typical mid-Holocene increase of alder usually reported in this region, e.g., by Colinvaux [18], Anderson and Brubaker [1], and Eisner et al. [21], is not observed, pointing towards a young depositional environment for our record of $<4000$ cal yr BP.

The initial Peatball Lake basin likely deepened rapidly with laminated lake sediments accumulating early on above the preserved wetland peat at the base of the central core P2 (Fig. 6, Phase A) and aquatic algae preserved in the sedimentary record (Fig. 4). The initial pond may have evolved at the intersection of ice wedges where degradation and impoundment of water at troughs can lead to the formation of small but $>1.5-\mathrm{m}$ deep ponds [45]. Ice wedge networks are present in the modern catchment (Fig. 1), and their high ground ice content is crucial for deeper thawing and thermokarst development [40]. Previous studies have shown that the depth of ice wedges is generally limited to a maximum of 6-8 $\mathrm{m}$ in areas affected by multiple thermokarst lake cycles [40]. It is even more likely that the early Peatball Lake initiated from a remnant pond located in one of the DTLBs situated in the catchment of the modern Peatball Lake basin. A shallow lake has either persisted in the DTLB or a secondary, new thermokarst lake developed. Secondary thermokarst lakes are typically (1) small and shallow ponds at the low-lying margins or (2) slightly deeper and larger lakes in the basin center created by thawing into ice- and organic-rich lacustrine material of a drained primary thermokarst lake [45]. Both have been observed in recent basins of Alaskan permafrost lowlands $[40,43,45,56]$ or interpreted in paleo-records [57]. In the early stage of Peatball Lake development, the winter lake ice cover apparently has not disturbed the sediment layering. Increasing oxygenation at the central part of the lake was derived from a high $\mathrm{Fe} / \mathrm{Ti}$ and $\mathrm{Fe} / \mathrm{S}$ ratio in core $\mathrm{P} 2$. Oxygenation in Arctic lakes is not only an indicator for increased water depth but also is dependent on winter lake ice thickness, which reduces the water volume over lake sediments. The winter ice cover of $>1 \mathrm{~m}$ thickness of modern Peatball Lake do not only cause typical cold-monomictic water circulations but is also responsible for the concentration of ions in the reduced water volume (Table 1). In phase $C$ of Peatball Lake (Fig. 6), increased oxygenation indicates a shift in ice cover from bedfast ice to floating ice conditions with increasing water depth. Low $\mathrm{Fe} / \mathrm{Ti}$ and $\mathrm{Fe} / \mathrm{S}$ ratios in core $\mathrm{P} 1$ reflect predominantly anoxic conditions for the nearshore zone reasoned by bedfast ice in shallow waters. However, Fe/Ti and Fe/S ratios at the core base of $\mathrm{P} 1$ are surprisingly high and most likely indicate in situ terrestrial peat which deposited under atmospheric conditions before the lake expanded into the $\mathrm{P} 1$ coring site. This signal is less obvious in the Fe/Ti and $\mathrm{Fe} / \mathrm{S}$ records of the central core $\mathrm{P} 2$.

After its initiation and deepening, Peatball Lake predominately expanded laterally through thermal and mechanical erosion (Fig. 6, Phases B and C). The larger the lake surface area, the longer the wind fetch and the greater the shoreline erosion due to mechanical wave action [45]. In addition, water depth exceeding the maximum lake ice thickness in winter has been linked to higher rates of shoreline erosion [6]. Although the modern shoreline
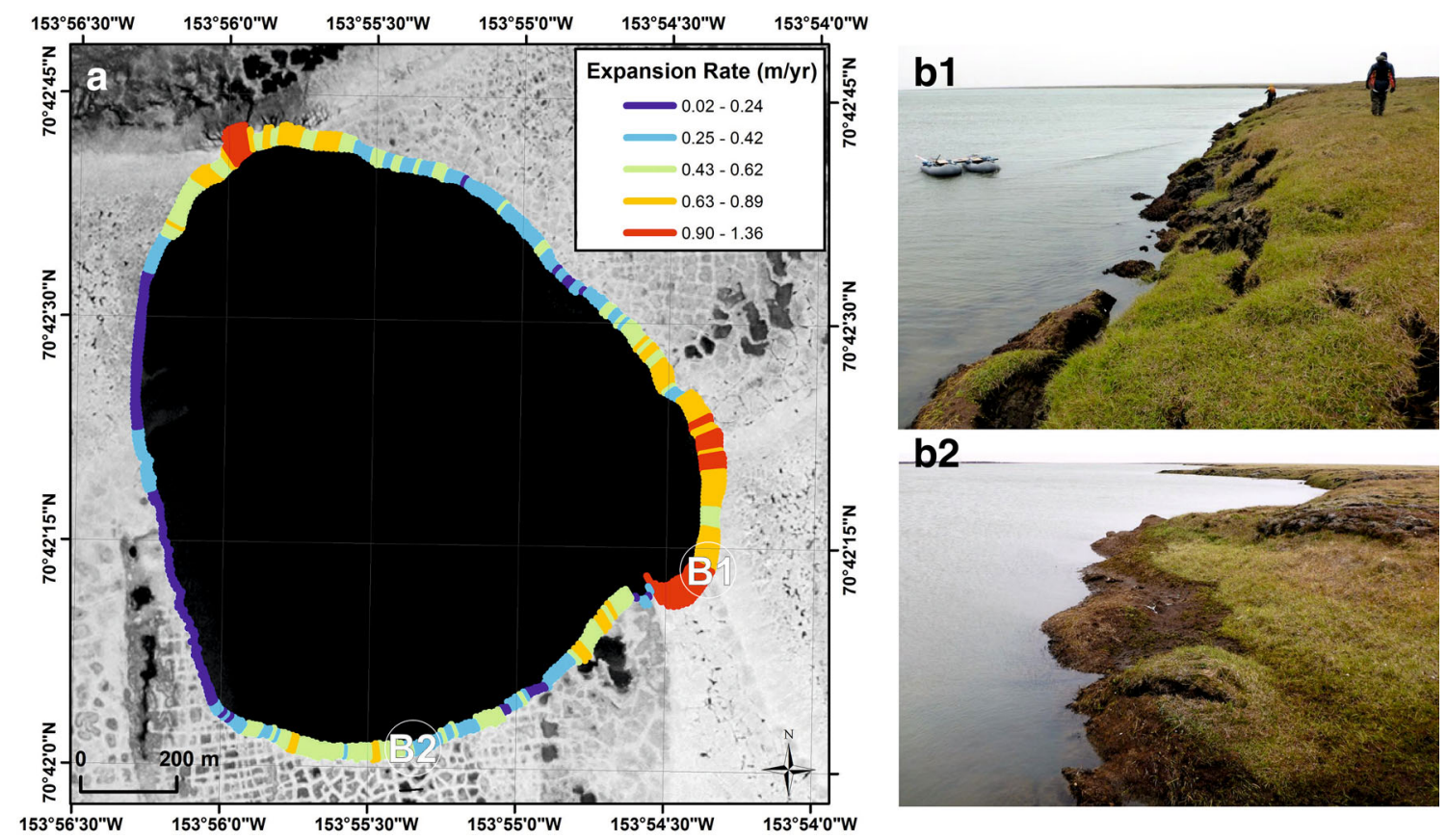

Fig. 5 a Expansion rates of Peatball Lake between 1955 and 2002 at $10 \mathrm{~m}$ increments. b1 Upland bluff to the SE and b2 lowland along a DTLB, SSW of Peatball Lake 


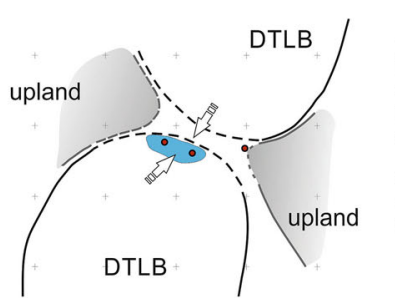

Phase A:

Initial phase of Peatball Lake

around 1400 years ago,

an older DTLB

$m$ sediment source:

redeposited thermokarst

sediments

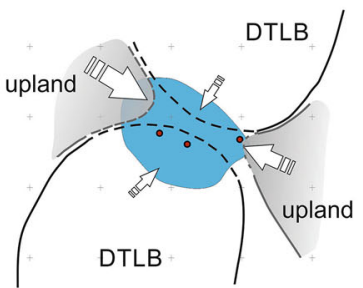

Phase B:

Expansion of Peatball Lake into upland remnants and DTLBs

ㄸ $>$ sediment source: strong influence of upland sediments lake sediments

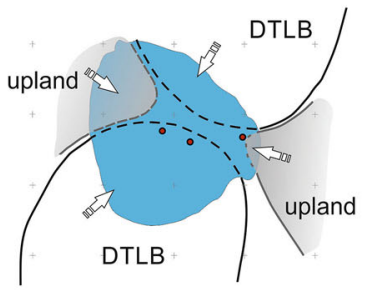

Phase C:

Modern Peatball Lake expansio into DTLBs and upland remnants

$m>$ sediment source: redeposited thermokarst basins and upland deposits likely as a remnant lake of next to redeposited thermokarst balanced between by
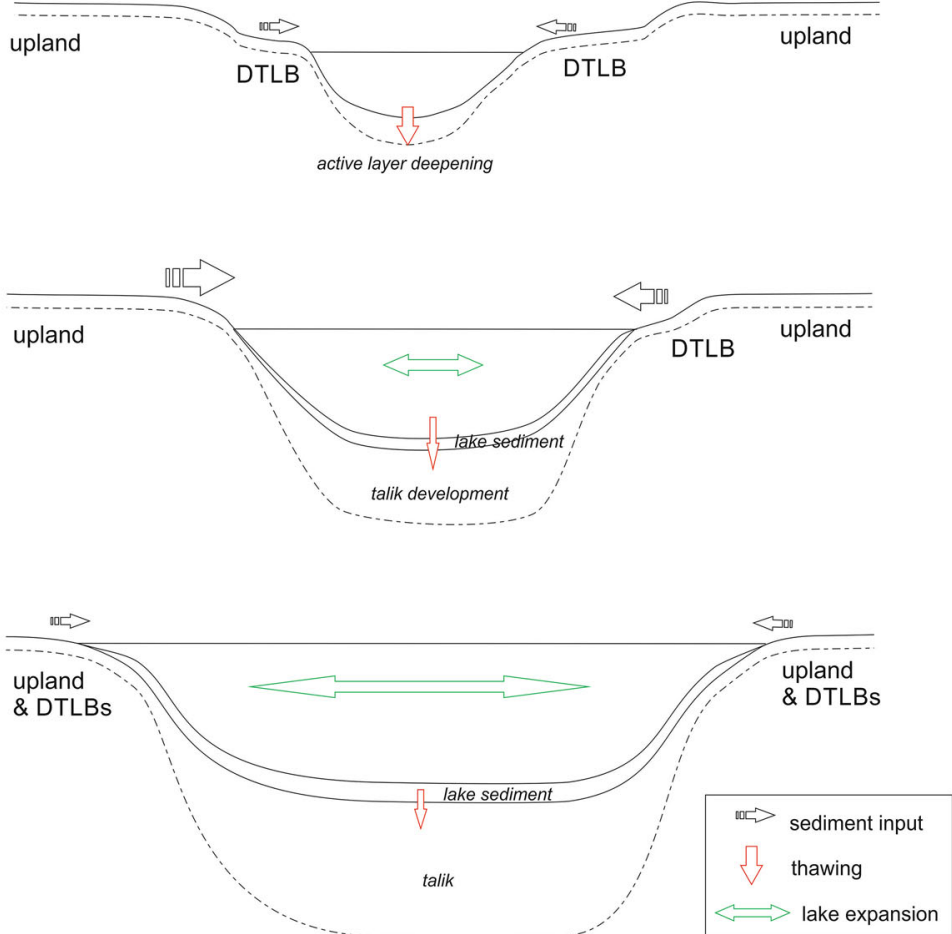

Fig. 6 Development of Peatball Lake and indication of changing sediment sources; red dots indicate the coring locations (Fig. 1): Phase A Initial lake development and deep thawing around 1400 years ago as a remnant of a former thermokarst lake and

expansion rate of Peatball Lake ranges from 0.02 to $1.36 \mathrm{~m}$ $\mathrm{yr}^{-1}$, the lake likely enlarged radially which is typical for most thermokarst lakes [40], but does not follow the typical pattern of north-south lake elongation observed in most of the Teshekpuk Lake Special Area [6, 16, 38]. The formation of oriented lakes is still not yet fully understood, but it seems widely accepted that sublittoral shelves form by nearshore wind-driven currents, which are perpendicular to the prevailing easterly and westerly winds, protecting subsequently the eastern and western lake shores from thawing and erosion due to lower wave height and energies in shallow waters [16]. In Peatball Lake, a sublittoral shelf is clearly evident from the bathymetry on the western shore and is present, although less clear, at the eastern shore (Fig. 1) suggesting an increasing elongation for Peatball Lake's future development. This could include tapping and drainage into the older DTLB to the north or into Teshekpuk Lake to the south in the future.

\section{Impact of catchment genesis and morphology on the lake sediment record}

During the lake expansion process, the eroding shorelines intersected sediment sources of different genesis and morphology. A homogenous, clastic dominated sediment redeposited lacustrine sediments as predominant sediment source. Phase $B$ Lateral lake expansion into upland deposits and talik development. Phase $C$ Expansion of Peatball Lake into DTLBs and upland remains

facies in 71-87 $\mathrm{cm}$ depth of the otherwise layered central core $\mathrm{P} 2$ points towards alternating deposition conditions. In this section, low accumulation of organic matter indicates rapid deposition of clastic material and high magnetic susceptibility indicates a change of external sediment sources in the catchment. Old radiocarbon dates of up to $4200 \pm 125$ cal yr BP in this section of core P2 (Table 3) indicate the influence of a different sediment source which likely is associated with the neighboring upland remains dated to at least $6840 \pm 100 \mathrm{cal} \mathrm{yr}$ BP (in depth of 156-159 cm, Poz-74,869, core ID Tes-UPL-2, Fig. 1, S. Jock, unpublished data). The sediment record hence archived the history of a growing Peatball Lake which initiated in a DTLB (Phase A) and, subsequently, expanded laterally into upland remnants and also DTLBs (Phases B and C, Fig. 6). When shore erosion reached the uplands, higher sediment fluxes with occasional thaw slumping were likely due to the steeper geomorphological gradient of several meters between lake and upland. Biskaborn et al. [9] reconstructed different states of slope stability, including slumping events from ice wedge structures, in the sedimentary record of a Siberian thermokarst lake in a less heterogeneous catchment with higher relief energy. In Peatball Lake, the relief energy is lower, but the sediment source suddenly changed from lacustrine, reworked 
deposits of DTLBs in Phase A to predominately upland deposits in Phase B, and gradually to a mixture of both DTLB and upland deposits in Phase C.

The nearshore core P1 is situated close to the today's upland in the eastern catchment and confirms a similar depositional environment like Phase B in core P2: rapid, event-like deposition is indicated by radiocarbon ages as young as $180 \pm 50 \mathrm{cal} \mathrm{yr}$ BP in $48 \mathrm{~cm}$ depth, a step-like increase in magnetic susceptibility at 45,31 , and $20 \mathrm{~cm}$ and low organic matter content. $\mathrm{C} / \mathrm{N}$ and $\delta^{13} \mathrm{C}$ are more variable in nearshore sediments indicating a dynamic organic matter accumulation of different qualities and origins. The XRF-based ratio of $\mathrm{K} / \mathrm{Ti}$ points to a generally constant clastic sediment source for the nearshore and lake center, which is explained by short transport paths of redistributed sediments of initially the same origin.

\section{Carbon degradation}

The variability of AMS radiocarbon ages in all three Peatball Lake cores highlights that old permafrost carbon is continuously recycled and redeposited in thermokarst landscapes of the Alaskan Arctic Coastal Plain. When located in thawed sediments, the old reworked carbon is affected by ongoing decomposition by microbial communities and the response to warmer temperatures is a key factor for changes in local carbon cycling [50]. Average organic carbon content of sediments in the central part of Peatball Lake $\left(\mathrm{TOC}_{\text {average }}=7 \mathrm{wt} \%\right.$ in P2 and P3) was four times lower and nearshore deposits $\left(\mathrm{TOC}_{\text {average }}=1.6 \mathrm{wt} \%\right.$ in P1) were even more than 18 times lower than upland deposits from the eastern catchment $\left(\mathrm{TOC}_{\text {average }}=30 \mathrm{wt} \%\right.$ in a $190-\mathrm{cm}$ upland permafrost core Tes-UPL-2, S. Jock, unpublished data). Similar relationships were investigated for total nitrogen which was three times lower in central Peatball Lake sediments $\left(\mathrm{TN}_{\text {average }}=0.5 \mathrm{wt} \%\right.$ in $\mathrm{P} 2$ and P3) and seven times lower than in nearshore deposits $\left(\mathrm{TN}_{\text {average }}=0.2 \mathrm{wt} \%\right.$ with $\mathrm{TN}$ under detection limit of 0.1 wt\% in large parts of P1) than in terrestrial upland deposits $\left(\mathrm{TN}_{\text {average }}=1.4 \mathrm{wt} \%\right.$ in Tes-UPL-2, S. Jock, unpublished data). Old organic matter is significantly affected by permafrost degradation during the process of thawing and decomposition [67]. The degraded organic material is relocated by thermokarst erosion and accumulated in the lake basin. Rapid nearshore deposition of degraded material and low primary production under Arctic climate and anoxic conditions in shallow waters result in nutrient-poor sublittoral sediment deposition as reflected in sediment core P1. Due to wave action in windy environments, lowmass organics may also get transported into deeper deposits. Furthermore, finer sediments were relocated and accumulated in the deeper basin where a vertically mixed water body enhanced primary production in summer and

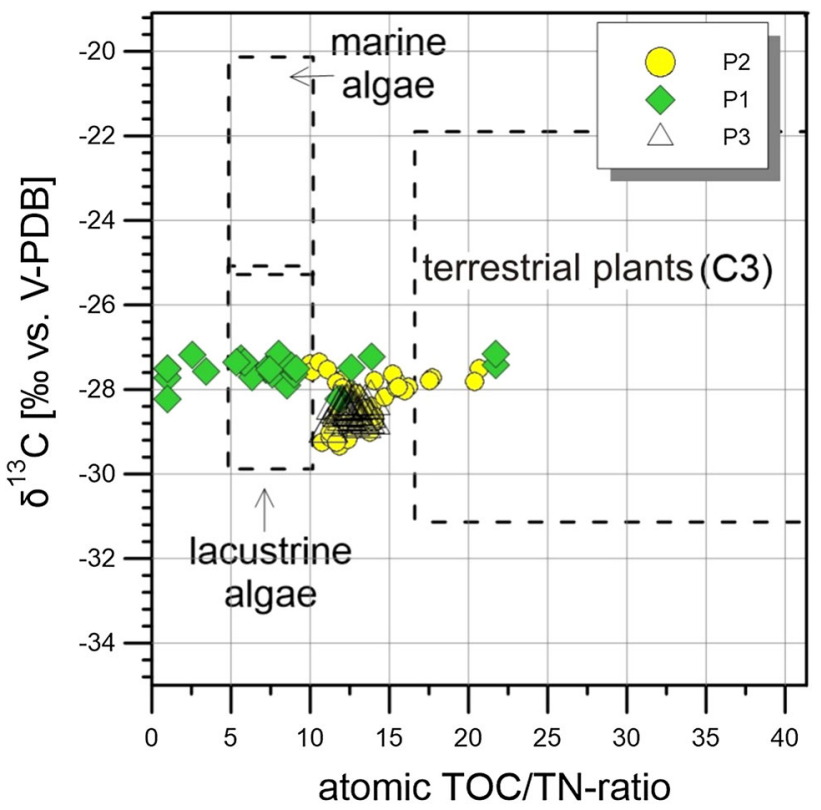

Fig. 7 Ratio of $\delta{ }^{13} \mathrm{C}$ and TOC/TN of all Peatball Lake cores (P1, P2, and $\mathrm{P} 3$ ) presented relative to ranges of organic matter produced by $\mathrm{C} 3$ terrestrial plants, marine algae and lacustrine algae (according to Meyers [61] and Meyers and Lallier-Verges [63])

enrichment of lacustrine organic matter in the sediment [17]. Aquatic algae were present throughout the full sediment record of P2 (namely, Botryococcus and Pediastrum, Fig. 7) giving evidence for sufficient primary production in the short growing season. Increasing oxic water conditions as evident from higher $\mathrm{Fe} / \mathrm{Ti}$ and $\mathrm{Fe} / \mathrm{S} \mathrm{XRF}$ ratios (Fig. 3) and modern dissolved oxygen of $>100 \%\left(>10 \mathrm{mg} \mathrm{L}^{-1}\right.$, Table 1) of lake water in summer supports the higher bioproductivity in an expanding lake. Furthermore, nitrogen becomes relatively enriched as carbon decomposition is presumably higher in oxic water conditions. A higher rate of decomposition due to longer residence times in unfrozen lake sediments result in lower $\mathrm{C} / \mathrm{N}$-ratios. The on average three times lower $\mathrm{C} / \mathrm{N}$-ratio in nearshore sediments (on average 7 in $\mathrm{P} 1$ ranging from close to 0 where TOC and $\mathrm{TN}$ is below the detection limit to 22) than in upland deposits (22 in Tes-UPL-2, Fig. 1, S. Jock, unpublished data) highlights the high degree of decomposition. The generally wide range of $\mathrm{C} / \mathrm{N}$ in core $\mathrm{P} 1$ (Fig. 7) points at a wide range of organic matter sources from typically terrestrial land plants to lacustrine algae, whereas the central core $\mathrm{P} 2$ shows a similar signature with less variability. However, it is possible that inorganic nitrogen from marine sands and silts also have reduced the $\mathrm{C} / \mathrm{N}$ ratio derived from total nitrogen.

Mueller et al. [67] have shown that large amounts of labile organic carbon are stored in deposits of drained lake basins on Barrow Peninsula $\left(42 \pm 5 \mathrm{~kg} \mathrm{~m}^{-3}\right.$ in young 
basins $<50$ years old and up to $62.5 \pm 14 \mathrm{~kg} \mathrm{~m}^{-3}$ in old basins 300-2000 years old) and confirmed a major carbon stock in the active layers as previously described by Bockheim et al. [11]. It is also evident that the largest amounts of organic carbon $\left(>25 \mathrm{~kg} \mathrm{~m}^{-2}\right)$ are stored as easy degradable organic matter in carbohydrates and only $\sim 10 \mathrm{~kg} \mathrm{~m}^{-2}$ are stored as mineral associated, thus more stable, organic matter [67]. Although we have no samples of DTLBs in the catchment of Peatball Lake for comparison, it can be assumed that the organic matter content is lower in thermokarst affected terrain where unfrozen organic matter was potentially recycled repeatedly during several lake generations like shown in previous studies from the northern Seward Peninsula [57].

\section{Conclusions}

Our study of lake expansion and sedimentary records of Peatball Lake on the Alaska Arctic Coastal Plain reflects the landscape and sediment dynamics of typical ice-rich permafrost lowlands affected by thermokarst activity. The main conclusions of the study are as follows:

1. The development of a late Holocene thermokarst lake on the Arctic Coastal Plain was delineated by sedimentary records and remotely sensed imagery. Radiocarbon dating in this periglacial environment is problematic due to input of organic matter into the lake from permafrost deposits along eroding lake shores. However, ${ }^{210} \mathrm{~Pb} /{ }^{137} \mathrm{Cs}$ and multiple ${ }^{14} \mathrm{C}$ dating together with the calculation of the lake expansion rates of the last 47 years allow estimating the minimum lake age of 1400 years. As derived from lithological, geochemical and vegetation data, Peatball Lake likely initiated as a remnant lake from DTLB (Phase A), deepened rapidly and expanded radially into surrounding DTLBs and uplands (Phases B and C).

2. Sedimentological analyses of the cores show lakeinternal variability in sediment deposition and reflect the impact of landscape morphology and genesis in the catchment of thermokarst lakes on sedimentation dynamics. As derived from lithological and geochemical proxies, the sediment source has changed during lake expansion from predominantly redeposited, thermokarst deposits from DTLBs (Phase A) to a sudden input of older, not yet, relocated upland deposits (Phase B), to a combination of upland and DTLBs as sediment source (Phase C).

3. The sedimentary record highlights that old carbon is being recycled by permafrost thaw and thermokarst processes. Organic matter content was significantly lower in lake sediments than in neighboring organic- rich, peaty upland deposits. Nearshore sediments showed very low average TOC of $1.6 \mathrm{wt} \%$ and TN of $0.2 \mathrm{wt} \%$ and had indication for a wide range of lacustrine to terrestrial organic matter sources.

The sedimentary records of Peatball Lake demonstrate the high complexity of depositional environments in thermokarst lakes due to the spatio-temporal changes in lake morphology as well as in the surrounding landscape. Reshaping of permafrost regions by multiple lake generations generate a diversity of catchment situations that may affect depositional patterns within lakes differently. This needs to be taken into account when interpreting thermokarst lake cores and implications for biogeochemical cycling and carbon stocks of Arctic thermokarst landscapes.

\section{Electronic supplementary material}

The online version of this article (doi:10.1007/s41063-0160025-0) contains supplementary material, which is available to authorized users, and the data presented here are available on PANGAEA (https://doi.org/10.1594/PAN GAEA.864814).

Acknowledgements This research was primarily supported by a $\mathrm{PhD}$ stipend of the University of Potsdam and a grant by the Christiane Nüsslein-Volhard-Foundation awarded to J. Lenz, and a grant of the European Research Council (\#338335) awarded to G. Grosse. Field work was enabled through the CALON project (www.arcticlakes.org) and the Teshekpuk Lake Observatory (www.teshekpuklake.com). We wish to thank C. Baughman (USGS) and Jim Webster (Webster's Flying Service) for help in the field, I. Nitze for bathymetric measurements and map preparation, N. Nowaczyk (GFZ) for MS measurements, J. Thom and S. Jock for help in the lab, J. Wolter for macrofossil determination for radiocarbon dating and B. Niemeyer for pollen preparation. The study contributes to the Arctic Ecological Network (Arc-EcoNet; Federal Ministry of Education and Research Grant No. 01DJ14003). N. Rudaya performed this study according to the Russian Government Program of Competitive Growth of the Kazan Federal University. Any use of trade, product, or firm names is for descriptive purposes only and does not imply endorsement by the US Government. We wish to thank B. Ganglioti and an anonymous reviewer for their helpful comments.

\section{References}

1. Anderson PM, Brubaker LB (1994) Vegetation history of northcentral Alaska: a mapped summary of late-quaternary pollen data. Quatern Sci Rev 13(1):71-92

2. Appleby PG, Nolan PJ, Gifford DW, Godfrey MJ, Oldfield F, Anderson NJ, Battarbee RW (1986) ${ }^{210} \mathrm{~Pb}$ dating by low background gamma counting. Hydrobiologia 141:21-27

3. Appleby PG, Richardson N, Nolan PJ (1992) Self-absorption corrections for well-type germanium detectors. Nucl Inst Methods B 71:228-233

4. Arp CD, Jones BM, Liljedahl AK, Hinkel KM, Welker JA (2015) Depth, ice thickness, and ice-out timing cause divergent hydrologic responses among Arctic lakes. Water Resource Res 51(12):9379-9401 
5. Arp CD, Jones BM, Lu Z, Whitman MS (2012) Shifting balance of thermokarst lake ice regimes across the Arctic Coastal Plain of northern Alaska. Geophys Res Lett 39:L16503

6. Arp CD, Jones BM, Urban FE, Grosse G (2011) Hydrogeomorphic processes of thermokarst lakes with grounded-ice and floating-ice regimes on the Arctic coastal plain, Alaska. Hydrol Process 25(15):2422-2438

7. Beug HJ (2004) Leitfaden der Pollenbestimmung. Verlag Dr Friedrich Pfeil, München

8. Biskaborn BK, Herzschuh U, Bolshiyanov DY, Savelieva L, Zibulski R, Diekmann B (2013) Late Holocene thermokarst variability inferred from diatoms in a lake sediment record from the Lena Delta, Siberian Arctic. J Paleolimnol 49:155-170

9. Biskaborn BK, Herzschuh U, Bolshiyanov DY, Schwamborn G, Diekmann B (2013) Thermokarst processes and depositional events in a Tundra Lake, Northeastern Siberia. Permafr Periglac Process 24(3):160-174

10. Black R, Barksdale W (1949) Oriented lakes of northern Alaska. J Geol 57:105-118

11. Bockheim JG, Everett LR, Hinkel KM, Nelson FE, Brown J (1999) Soil organic carbon storage and distribution in Arctic Tundra, Barrow, Alaska. Soil Sci Soc Am J 63:934-940

12. Bowden WB, Gooseff MN, Balser A, Green A, Peterson BJ, Bradford J (2008) Sediment and nutrient delivery from thermokarst features in the foothills of the North Slope, Alaska: potential impacts on headwater stream ecosystems. J Geophy Res 113:G02026

13. Brewer MC (1958) The thermal regime of an arctic lake. Trans AGU 39:278-284

14. Brigham-Grette J, Carter LD (1992) Pliocene marine transgressions of northern Alaska: circumarctic correlations and paleoclimate interpretations. Arctic 45:74-89

15. Brigham-Grette J, Hopkins D (1995) Emergent marine record and paleoclimate of the last interglaciation along the Northwest Alaskan Coast. Quatern Res 43:159-173

16. Carson C, Hussey K (1962) The oriented lakes of arctic Alaska. J Geol 70:417-439

17. Cohen AS (2003) Paleolimnology: the history and evolution of lake systems. Oxford University Press, Oxford

18. Colinvaux PA (1964) The environment of the Bering Land Bridge. Ecol Monogr 34(3):296-329

19. Coulombe O, Bouchard F, Pienitz R (2016) Coupling of sedimentological and limnological dynamics in subarctic thermokarst ponds in Northern Québec (Canada) on an interannual basis. Sed Geol 340:15-24

20. Croudace IW, Rindby A, Rothwell RG (2006) ITRAX: description and evaluation of a new multi-function X-ray core scanner. In: Rothwell RG (ed) New techniques in sediment core analysis: Geological Society, London, Special Publications, 267, pp. 51-63

21. Eisner WR, Bockheim JG, Hinkel KM, Brown TA, Nelson FE, Peterson KM, Jones BM (2005) Paleoenvironmental analyses of an organic deposit from an erosional landscape remnant, Arctic Coastal Plain of Alaska. Palaeogeogr Palaeoclimatol Palaeoecol 217(3): 187-204

22. van Everdingen RO (2005) Multi-language glossary of permafrost and related ground-ice terms. National Snow and Ice Data Center/World Data Center for Glaciology, Boulder

23. Fægri K, Iversen J (1989) Textbook of pollen analysis, 4th edn. Wiley, Chichester

24. Farquharson L, Walter Anthony KM, Bigelow N, Edwards M, Grosse G (2016) Facies analysis of yedoma thermokarst lakes on the northern Seward Peninsula, Alaska. Sed Geol 340:25-37

25. Farquharson LM, Mann DH, Grosse G, Jones BM, Romanovsky VE (2016) Spatial distribution of thermokarst terrain in Arctic Alaska. Geomorphology 273:116-133
26. French HM (2007) The periglacial environment, 3rd edn. Wiley, London

27. Fritz M, Unkel I, Lenz J, Gajewski K, Frenzel P, Paquette N, Lantuit H, Körte L, Wetterich S (under review). Regional environmental change versus local signal preservation in Holocene thermokarst lake sediments: a case study from Herschel Island, Yukon (Canada). J Paleolimnol

28. Fritz M, Wetterich S, Schirrmeister L, Meyer H, Lantuit H, Preusser F, Pollard WH (2012) Eastern Beringia and beyond: late Wisconsinan and Holocene landscape dynamics along the Yukon Coastal Plain, Canada. Palaeogeogr Palaeoclimatol Palaeoecol 319-320:28-45

29. Fritz M, Wolter J, Rudaya N, Palagushkina O, Nazarova L, Obu J, Rethemeyer J, Lantuit H, Wetterich S (2016) Holocene icewedge polygon development in northern Yukon permafrost peatlands (Canada). Quatern Sci Rev 147:279-297

30. Frohn RC, Hinkel KM, Eisner WR (2005) Satellite remote sensing classification of thaw lakes and drained thaw lake basins on the North Slope of Alaska. Remote Sens Environ 97(1):116-126

31. Gaglioti BV, Mann DH, Jones BM, Pohlman JW, Kunz ML, Wooller MJ (2014) Radiocarbon age-offsets in an arctic lake reveal the long-term response of permafrost carbon to climate change. J Geophys Res Biogeosci 119:1630-1651

32. Godin E, Fortier D (2012) Geomorphology of a thermo-erosion gully, Bylot Island, Nunavut, Canada. Can J Earth Sci 49:979-986

33. Grimm E (1987) CONISS: a FORTRAN 77 program for stratigraphically constrained cluster analysis by the methods of incremental sum of squares. Comput Geosci 13:13-15

34. Grosse G, Jones BM, Arp CD (2013) Thermokarst lakes, drainage, and drained basins. In: John F Shroder (chief ed.), Giardino R, Harbor J (vol. ed) Treatise on geomorphology, vol 8, Glacial and periglacial geomorphology. Academic Press, San Diego, pp. $325-353$

35. Grosse G, Romanovsky VE, Jorgenson T, Anthony KMW, Brown J, Overduin PP (2011) Vulnerability and feedbacks of arctic permafrost to climate change. EOS Trans Am Geophys Union 9(1):73-74

36. Heslop JK, Anthony KMW, Sepulveda-Jauregui A, MartinezCruz K, Bondurant A, Grosse G, Jones MC (2015) Thermokarstlake methanogenesis along a complete talik profile. Biogeosciences 12:4317-4331

37. Hinkel KM, Eisner WR, Bockheim JG, Nelson FE, Peterson KM, Dai X (2003) Spatial extent, age, and carbon stocks in drained Thaw Lake basins on the barrow Peninsula, Alaska. Arct Antarct Alp Res 35:291-300

38. Hinkel KM, Frohn RC, Nelson FE, Eisner WR, Beck RA (2005) Morphometric and spatial analysis of thaw lakes and drained thaw lake basins in the western Arctic Coastal Plain, Alaska. Permafrost Periglac Process 16:327-341

39. Hinkel KM, Sheng Y, Lenters JD, Lyons EA, Beck RA, Eisner WR, Wang J (2012) Thermokarst lakes on the arctic Coastal plain of Alaska: geomorphic controls on bathymetry. Permafrost Periglac Process 23:218-230

40. Hopkins DM, Kidd JG (1988) Thaw lake sediments and sedimentary environments. In: Senneset $\mathrm{K}$ (ed) 5th International permafrost conference. Tapir Publishers, Trondheim, pp 790-795

41. Jones MC, Grosse G, Jones BM, Anthony KMW (2012) Peat accumulation in drained thermokarst lake basins in continuous, ice-rich permafrost, northern Seward Peninsula, Alaska. J Geophys Res Biogeosci 117:G2

42. Jones BM, Arp CD (2015) Observing a catastrophic thermokarst lake drainage in northern Alaska. Permafrost Periglac Process 26:119-128

43. Jones BM, Grosse G, Arp CD, Jones MC, Walter Anthony KM, Romanovsky VE (2011) Modern thermokarst lake dynamics in 
the continuous permafrost zone, northern Seward Peninsula, Alaska. J Geophys Res 116:G00M03

44. Jones BM, Grosse G, Arp CD, Miller E, Liu L, Hayes DJ, Larsen CF (2015) Recent Arctic tundra fire initiates widespread thermokarst development. Sci Rep 5:15865

45. Jorgenson MT, Shur Y (2007) Evolution of lakes and basins in northern Alaska and discussion of the thaw lake cycle. J Geophys Res Earth Surf 112:F02S17

46. Jorgenson MT, Shur Y, Pullman ER (2006) Abrupt increase in permafrost degradation in Arctic Alaska. Geophys Res Lett 33:L02503

47. Jorgenson MT, Romonovsky V, Yoshikawa K, Kanevskiy M, Shur Y, Marchenko S, Brown J, Jones B (2008) Permafrost characteristics of Alaska-a new permafrost map of Alaska. In: Henkel KM (ed) 9th International conference on permafrost. Institute of Northern Engineering, Fairbanks, University of Alaska, pp 121-122

48. Kanevskiy M, Shur Y, Fortier D, Jorgenson MT, Stephani E (2011) Cryostratigraphy of late Pleistocene syngenetic permafrost (yedoma) in northern Alaska, Itkillik River exposure. Quat Res 75(3):584-596

49. Kanevskiy M, Shur Y, Jorgenson MT, Ping CL, Michaelson GJ, Fortier D, Stephani E, Dillon M, Tumskoy V (2013) Ground ice in the upper permafrost of the Beaufort Sea coast of Alaska. Cold Reg Sci Technol 85:56-70

50. Kao-Kniffin J, Woodcroft BJ, Carver SM, Bockheim JG, Handelsman J, Tyson GW, Hinkel KM, Mueller CW (2015) Archaeal and bacterial communities across a chronosequence of drained lake basins in arctic alaska. Nat Sci Rep 5:18165

51. Klein ES, Yu Z, Booth RK (2013) Recent increase in peatland carbon accumulation in a thermokarst lake basin in Southwestern Alaska. Palaeogeogr Palaeoclimatol Palaeoecol 39:186-195

52. Kokelj SV, Lantz TC, Kanigan J, Smith SL, Coutts R (2009) Origin and polycyclic behaviour of tundra thaw slumps, Mackenzie Delta Region, Northwest Territories, Canada. Permafrost Periglac Process 20:173-184

53. Lamoureux SF, Gilbert R (2004) Physical and chemical properties and proxies of high latitude lake sediments. In Pienitz R, Douglas MSV, Smol JP (eds) Long-term environmental change in Arctic and Antarctic Lakes, vol 8, Springer, pp. 53-87

54. Lantuit H, Pollard WH, Couture N, Fritz M, Schirrmeister L, Meyer H, Hubberten HW (2012) Modern and late Holocene retrogressive thaw slump activity on the Yukon coastal plain and Herschel Island, Yukon Territory, Canada. Permafr Periglac Process 23(1):39-51

55. Lenz J, Fritz M, Schirrmeister L, Lantuit H, Wooller MJ, Pollard WH, Wetterich S (2013) Periglacial landscape dynamics in the western Canadian Arctic: results from a thermokarst lake record on a push moraine (Herschel Island, Yukon Territory). Palaeogeogr Palaeoclimatol Palaeoecol 381-382:15-25

56. Lenz J, Grosse G, Jones BM, Anthony KMW, Bobrov A, Wulf S, Wetterich S (2016) Mid-Wisconsin to Holocene permafrost and landscape dynamics based on a drained lake basin core from the northern Seward Peninsula, northwest Alaska. Permafrost Periglac Process 27:56-75

57. Lenz J, Wetterich S, Jones BM, Meyer HM, Bobrov A, Grosse G (2016) Evidence of multiple thermokarst lake generations from an 11,800-years-old permafrost core on the northern Seward Peninsula, Alaska. Boreas 45(4):584-603

58. Ling F, Zhang T (2003) Numerical simulation of permafrost thermal regime and talik development under shallow thaw lakes on the Alaskan Arctic Coastal Plain. J Geophys Res 108:4511

59. Meyer H, Opel T, Laepple T, Dereviagin AY, Hoffmann K, Werner M (2015) Long-term winter warming trend in the Siberian Arctic during the mid-to late Holocene. Nat Geosci 8(2):122-125
60. Meyer H, Schirrmeister L, Yoshikawa K, Opel T, Wetterich S, Hubberten HW, Brown J (2010) Permafrost evidence for severe winter cooling during the Younger Dryas in northern Alaska. Geophys Res Lett 37:L03501

61. Meyers PA (1994) Preservation of elemental and isotopic source identification of sedimentary organic matter. Chem Geol 144:289-302

62. Meyers PA (1997) Organic geochemical proxies of paleoceanographic, paleolimnologic, and paleoclimatic processes. Org Geochem 27(5):213-250

63. Meyers PA, Lallier-Verges E (1999) Lacustrine sedimentary organic matter records of Late Quaternary paleoclimates. J Paleolimnol 21:345-372

64. Meyers PA, Takemura K (1997) Quaternary changes in delivery and accumulation of organic matter in sediments in Lake Biwa, Japan. J Paleolimnol 18:211-218

65. Moore PD, Webb JA, Collinson ME (1991) Pollen analysis, 2nd edn. Blackwell Scientific Publications, Oxford

66. Morgenstern A, Ulrich M, Günther F, Roessler S, Fedorova I, Rudaya N, Wetterich S, Boike J, Schirrmeister L (2013) Evolution of thermokarst in East Siberian ice-rich permafrost: a case study. Geomorphology 201:363-379

67. Mueller CW, Rethemeyer J, Kao-Kniffin J, Löppmann S, Hinkel KM, Bockheim JG (2015) Large amounts of labile organic carbon in permafrost soils of northern Alaska. Glob Change Biol 21(7):2804-2817

68. Murton JB, Whiteman CA, Waller RI, Pollard WH, Clark ID, Dallimore SR (2005) Basal ice facies and supraglacial melt-out till of the Laurentide Ice Sheet, Tuktoyaktuk Coastlands, western Arctic Canada. Quatern Sci Rev 24(5):681-708

69. Nowaczyk N, Haltia EM, Ulbricht D, Wennrich V, Sauerbrey MA, Rosén P, Vogel H, Francke A, Meyer-Jacob C, Andreev AA, Lozhkin AV (2013) Chronology of Lake El'gygytgyn sediments - a combined magnetostratigraphic, palaeoclimatic and orbital tuning study based on multi-parameter analyses. Climate Past 9:2413-2432

70. Raynolds MK, Walker DA, Maier HA (2005) Alaska Arctic Tundra Vegetation Map. Scale 1:4,000,000. Conservation of Arctic Flora and Fauna (CAFF) Map No. 2. U.S. Fish and Wildlife Service, Anchorage, Alaska

71. Reille M (1992) Pollen et Spores d'Europe et d'Afrique du Nord. Laboratoire de Botanique Historique et Palynologie. URA CNRS, Marseille, France

72. Reille M (1998) Pollen et spores d'Europe et d'Afrique du nord. Supplément 2. Laboratoire de botanique historique et palynologie. URA CNRS, Marseille, France

73. Reimer P, Bard E, Bayliss A, Beck J, Blackwell P, Bronk Ramsey C, Buck C, Cheng H, Edwards R, Friedrich M, Grootes P, Guilderson T, Haflidason H, Hajdas I, Hatté C, Heaton T, Hoffmann D, Hogg A, Hughen K, Kaiser K, Kromer B, Manning S, Niu M, Reimer R, Richards D, Scott E, Southon J, Staff R, Turney C, van der Plicht J (2013) IntCal13 and Marine13 radiocarbon age calibration curves $0-50,000$ years cal BP. Radiocarbon 55(4):1869-1887

74. Romanovsky VE, Sazonova TS, Balobaev VT, Shender NI, Sergueev DO (2007) Past and recent changes in air and permafrost temperatures in eastern Siberia. Global Planet Change 56(3-4):399-413

75. Romanovsky VE, Smith S, Christiansen H (2010) Permafrost thermal state in the polar Northern Hemisphere during the International Polar Year 2007-2009: a synthesis. Permafrost Periglac Process 21:106-116

76. Rowland JC, Jones CE, Altmann G, Bryan R, Crosby BT, Hinzman LD, Kane DL, Lawrence DM, Mancino A, Marsh P, McNamara JP, Romanvosky VE, Toniolo H, Travis BJ, Trochim E, Wilson CJ, Geernaert GL (2010) Arctic landscapes in 
transition: responses to Thawing permafrost. Eos Trans Am Geophys Union 91:229-230

77. Schleusner P, Biskaborn BK, Kienast F, Wolter J, Subetto D, Diekmann B (2015) Basin evolution and palaeoenvironmental variability of the thermokarst lake El'gene-Kyuele, Arctic Siberia. Boreas 44(1):216-229

78. Sellmann PV, Brown J, Lewellen RI, McKim H, Merry C (1975) The classification and geomorphic implications of thaw lakes on the Arctic coastal plain, Alaska. United States Army, CRREL Research Report 344

79. Thieler ER, Himmelstoss EA, Zichichi JL, Ergul A (2009) Digital shoreline analysis system (DSAS) version 4.0-An ArcGIS extension for calculating shoreline change: U.S. Geological survey open-file report 2008-1278

80. Tjallingii R, Röhl U, Kölling M, Bickert T (2007) Influence of the water content on X-ray fluorescence core-scanning measurements in soft marine sediments. Geochem Geophys Geosyst 8:Q02004

81. Anthony KMW, Zimov SA, Grosse G, Jones MC, Anthony PM, Chapin FS III, Finlay JC, Mack MC, Davydov S, Frenzel P, Frolking S (2014) A shift of thermokarst lakes from carbon sources to sinks during the Holocene epoch. Nature 511:452-456
82. Weltje GJ, Tjallingii R (2008) Calibration of XRF core scanners for quantitative geochemical logging of sediment cores: theory and application. Earth Planet Sci Lett 274:423-438

83. Wetterich S, Grosse G, Schirrmeister L, Andreev AA, Bobrov AA, Kienast F, Bigelow NH, Edwards ME (2012) Late Quaternary environmental and landscape dynamics revealed by a pingo sequence on the northern Seward Peninsula, Alaska. Quatern Sci Rev 39:26-44

84. Wetterich S, Kuzmina S, Andreev AA, Kienast F, Meyer H, Schirrmeister L, Kuznetsova T, Sierralta M (2008) Palaeoenvironmental dynamics inferred from late Quaternary permafrost deposits on Kurungnakh Island, Lena Delta, Northeast Siberia, Russia. Quat Sci Rev 27(15-16):1523-1540

85. Williams JR, Carter LD, Yeend WE (1978) Coastal plain deposits of NPRA. B20-22. In: Johnson KM (ed) The United States geological survey in Alaska: Accomplishments during 1977 (No. 772-B). Branch of Distribution, US Geological Survey

86. Wooller MJ, Pohlman JW, Gaglioti BV, Langdon P, Jones MC, Anthony KMW, Becker KW, Hinrichs WU, Elvert M (2012) Reconstruction of past methane availability in an Arctic Alaska wetland indicates climate influenced methane release during the past $\sim 12,000$ years. J Paleolimnol 48:27-42 